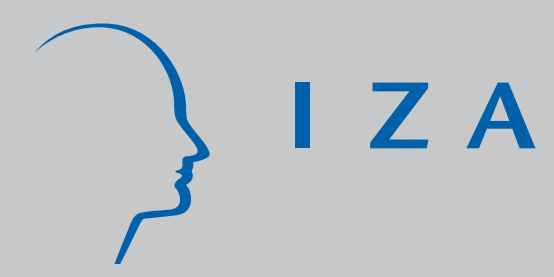

IZA DP No. 1459

Pupil Achievement, School Resources and Family Background

Torbjørn Hægeland

Oddbjørn Raaum

Kjell G. Salvanes

J anuary 2005 


\title{
Pupil Achievement, School Resources and Family Background
}

\author{
Torbjørn Hægeland \\ Statistics Norway \\ and Ragnar Frisch Centre for Economic Research \\ Oddbjørn Raaum \\ Ragnar Frisch Centre for Economic Research \\ Kjell G. Salvanes \\ Norwegian School of Economics and Business Administration, \\ Statistics Norway and IZA Bonn
}

\author{
Discussion Paper No. 1459 \\ January 2005
}

\author{
IZA \\ P.O. Box 7240 \\ 53072 Bonn \\ Germany \\ Phone: +49-228-3894-0 \\ Fax: +49-228-3894-180 \\ Email: iza@iza.org
}

\begin{abstract}
Any opinions expressed here are those of the author(s) and not those of the institute. Research disseminated by IZA may include views on policy, but the institute itself takes no institutional policy positions.

The Institute for the Study of Labor (IZA) in Bonn is a local and virtual international research center and a place of communication between science, politics and business. IZA is an independent nonprofit company supported by Deutsche Post World Net. The center is associated with the University of Bonn and offers a stimulating research environment through its research networks, research support, and visitors and doctoral programs. IZA engages in (i) original and internationally competitive research in all fields of labor economics, (ii) development of policy concepts, and (iii) dissemination of research results and concepts to the interested public.
\end{abstract}

IZA Discussion Papers often represent preliminary work and are circulated to encourage discussion. Citation of such a paper should account for its provisional character. A revised version may be available directly from the author. 


\section{ABSTRACT}

\section{Pupil Achievement, School Resources and Family Background*}

Whether increasing resource use in schools has a positive effect on pupil performance has occupied governments, parents and researchers for decades. A main challenge when trying to answer this question is to separate the effects of school resources from the effects of pupils' family background, since resources may be allocated in a compensatory manner, and pupils may sort into schools. We address these issues using a comprehensive dataset for two cohorts of pupils graduating from lower secondary school in Norway. The dataset is rich in performance measures, resource use variables and family background variables. As performance measures we use results at age 16 across 11 subjects, and we exploit the fact that we have both information from results from national exams and from continuous assessment in class. Controlling for family background, we find a positive but modest effect of resource quantity such as teacher hours per pupil, on pupil achievement. Observable teacher qualifications, within the variation present in lower secondary school in Norway, do not appear to have significant effects on school results. Resource quality as measured by teacher characteristics does not appear to have a significant impact on pupils' marks. We find clear evidence of compensating resource allocation and teacher sorting as well as relative setting of marks.

JEL Classification: $\quad 12$

Keywords: exam results, school resources, family background, compensating resource allocation

Kjell G. Salvanes

Department of Economics

Norwegian School of Economics and Business Administration

Helleveien 30

5035 Bergen-Sandviken

Norway

Email: kjell.salvanes@nhh.no

\footnotetext{
"This paper was prepared for "Technology and Change: Conference in memory of Tor Jakob Klette", University of Oslo, August 27-28, 2004. Thanks to Lars J. Kirkebøen for excellent research assistance, to participants at the conference in Oslo for comments and suggestions.
} 


\section{Introduction}

What makes pupils perform well at school? Does increased spending improve school results? These two questions have occupied governments, school authorities, teacher and parents for a long time. The reasons for this concern are obvious. There is mounting evidence that human capital investment is a key factor in economic growth. The trend towards greater public sector accountability implies an increasing focus on efficient resource allocation also in schools. On the individual level, school results, both in terms of quantity, measured by e.g. years of schooling, and in terms of quality, measured by e.g. grade point averages, exam results and test scores, are found to be key determinants of later labour market success in terms of earnings and employment. In many countries, educational policies, including the allocation of school resources, are designed to promote equality of opportunity by partly counteracting the effects of differences in family background.

These questions have also been debated in the academic literature for decades. Following the Coleman Report from 1966, which found that "it's all in the family", a large literature has attempted to estimate the effects the effects of school resources on pupil achievement. However, there is disagreement as to whether there are any effects of resources at all and, if any, how large they may be (Hanushek, 2003, Krueger, 2003). Similar studies have been undertaken on the link between resource use and school performance in Nordic schools. For instance, Bonesrønning (2003, 2004a, 2004b) has used survey data from Norway. The main result is that school resources have modest effects on pupil test scores.

Estimating the effects of school resources on pupil achievement in an attempt to identify causal links, poses methodological challenges. To some extent, the challenges arise because authorities and individuals believe that school resources are important for pupil achievement, and behave accordingly (see Todd and Wolpin, 2003). School authorities may direct extra resources to low-performing pupils and schools to improve their performance ('compensating resource allocation'). Parents may choose neighbourhoods and thereby schools for their children based on perceived school quality, which may be inferred from resource use. Teachers may also prefer working in schools with a high level of resources and a favourable pupil composition. This implies that neither pupils nor resources are randomly distributed across schools. The main methodological issue is how to separate effects of school resources on pupil performance from effects of pupils' family background. 
In the present paper we use a very rich matched register dataset for pupils and schools for two complete cohorts of pupils in the Norwegian lower secondary school, offering a number of avenues for research on this issue. The rich set of family background characteristics in our data set is very important in explaining student performance and thus helpful in conditioning out any sorting of student to schools by families sorting to neighbourhoods. Conditioning on pupils' family background, we are able to control for the compensatory nature of resource use and sorting of teachers when estimation regressions with and with family background variables. The rich data set also allows us to investigate whether the impact of resource use differs between low- and high-performing pupils, across subjects and across scores obtained by exam results and by assessments made in classrooms.

We find a positive but modest effect of resource quantity such as teacher hours per pupil, on school performance. Observable teacher qualifications, within the variation present in lower secondary school in Norway, do not appear to have significant effects on school results. We also find clear signs of compensating resource allocation and teacher sorting.

The paper unfolds as follows. In Section 2 and 3 we provide a short literature review and present the econometric specification. In Section 4 we present the data set, while the final two sections present the results and provide concluding remarks.

\section{Background and previous literature}

The modern literature on the effects of school resources and school organization on pupil achievement started with the Coleman Report in 1966 (Coleman et al., 1966). Coleman and his group of researchers collected nationwide data for the US on school inputs, socioeconomic background of pupils and test scores. School inputs had very little measurable impact on pupil achievement and school differences in pupil performance only accounted for 10-15 percent of the total variance. Family background and pupil composition had dominating effects. The main lesson from this study was that 'It's all in the family'. Thus, non-random distribution of pupils across schools means that adjustment for pupil composition is of vital importance when assessing school performance.

The literature on pupil achievement spurred by the Coleman report agrees upon the importance of family background, although the interpretation of this effect is far from straightforward. ${ }^{1}$ The question whether school resources matter for individual achievement,

\footnotetext{
1 A correlation between parents' education and children's test scores may reflect that clever parents get clever children that do well in school, or alternatively that there are other factors than education behind the good
} 
within the policy relevant set of input levels, is far more controversial. Most researchers seem to confirm the casual empiricism we all (?) have from own experiences; teacher 'quality' matters. In contrast, there is much less agreement when it comes to the effect of other school resources on pupil performance. ${ }^{2}$ The dispute is particularly strong regarding the impact of school resources measured by e.g. expenditures and teacher-pupil ratios on pupil achievement such as marks and test scores. In several studies, Eric Hanushek with coauthors do not find support for significant impacts of school resources on pupil test scores (for overviews see Hanushek, 1996, 2003). Measuring the effect of class size on test scores on Norwegian data, Bonesrønning, $(1996,2003)$ also find weak effects of class size. Other influential scholars like Alan Krueger with coauthors have identified positive effects of school resources on pupil test scores in several studies (Card and Krueger, 1992; Krueger and Lindahl, 2002 for Sweden, Krueger, 1999). Even survey articles, based on so-called meta analyses of the same selection of studies, conclude differently. While Hanushek (2003) interprets the literature as evidence supporting the view that standard school inputs like class size or expenditures have negligible effects on pupil achievement, Krueger (2003) draws the opposite conclusion. Interestingly, several studies find a significant impact of the same types of school resources on post-school outcomes like final educational attainment and earnings (Betts, 1996, Dearden, Ferri and Meghir, 2002, Dustmann, Rajan and Van Soest, 2003, Wilson, 2002).

Controlled experiments would allow us to identify the effect of school resources on pupil performance: Let's say we have two schools - one using a high level of resources per pupil (e.g. small classes) and one a low level of resources. If a random process splits the group of pupils in two and assigns each individual to one of the schools, no difference in (average) pre-school 'ability' would exist. If achievement could be measured by a test after, say, a year, the difference in the performance between the schools would provide an answer to whether more resources have an impact on average pupil performance, establishing one causal link between school resources and pupil performance (Krueger, 2003).

This type of experiments is not widely available and is hard to implement. In practice, we must rely on non-experimental data and alternative strategies are needed to solve

environment for bringing up children in a family with high education. Causal effects are hard to identify for family effects, hence it is also difficult to assess the effects of policies directed at increasing the equality of educational opportunities (see for instance Black, Devereux and Salvanes, 2003).

${ }^{2}$ Interestingly, until recently there has also been limited support for linking observable teacher characteristics to pupil performance. The main reason for this lack of support for the importance of teacher quality is probably that variation in teacher quality is driven by teacher characteristics that are difficult to measure and not necessarily strongly correlated with formal qualifications. Recent work do find support for the importance of teacher quality on student performance by using very detailed data on matched student-teacher data and thereby identifying teacher fixed effects (Hanushek et al. 2004; Rockoff, 2004). 
the inherit endogeneity problems. First, parents, teachers and pupils can adjust their behaviour in response to changes in school inputs and pupil composition. Second, school authorities and managers may adjust school resources to reflect different 'needs' arising form variation in pupil composition. Using class size as an example, pupil performance may vary across schools with small and large class sizes because of school policies, teacher adjustment and/or parental school choice, even in the absence of a causal class size effect. Teachers or school authorities may use small classes for less able pupils, parents may choose neighborhood based on perceived school quality (class size) and schools with small classes may also have other favourable characteristics (e.g. attracting good teachers). ${ }^{3}$ As noted by Lazear (2001), class size may also depend on how well-behaved children are in class and thus may well vary by neighbourhood characteristics, for instance.

The literature proposes two possible solutions to the endogeneity problem: 1) Natural experiments or instrumental variable estimators or 2) matching estimators. The typical example of the former strategy is to exploit exogenous variation in class size driven by maximum class size rule, (Angrist and Lavy, 1999; Hanushek, Rivkin and Kain, 1998; Hoxby, 2000; Browning and Heinesen, 2003, and for Norway see Bonesrønning, 2003). When the sizes of the age cohorts are randomly distributed across school catchment areas, an exogenous variation in class size will appear. These studies usually find very small or no effects of class size. Matching basically means that you 'mimic' the experiment design and construct a control group and a treatment group that are equal along observed variables (see Heckman, Ichimura and Todd, 1998). Machin and McNally (2004) use this strategy to find the effect of a change in organization of teaching on literacy in UK schools in 1997 and 1998. They do find non-negligible effect for weak pupils by re-organising existing resources in favour of weak pupils. The effects are stronger for boys than for girls and the effects appear to be persistent over time.

\section{Empirical strategy}

The general aim of this paper is to assess the effect of school resources and teacher qualifications, during the 3-year lower secondary school, on pupil achievement at age 16 in Norway. It is clear from the discussion above that our non-experimental data raise a number of problems when it comes to interpreting the association between school resources and pupil

\footnotetext{
${ }^{3}$ Another mechanism, analysed by Bonesrønning (2004a), could be that parents' effort towards children declines when class size is reduced.
} 
outcomes. We have to control for pupil heterogeneity and try to account for the adjustments made by parents, teachers and school authorities. This section describes how we deal with these problems.

A preferred approach to isolate the effect of school resources in providing pupils with cognitive skills from the effect of family background and previous schooling experience, is to treat the learning process as a cumulative process and to control for family background variables measured at different stages - reflecting preschool and probably even pre-birth resources of parents - as well as the impact of earlier school experience of the pupils (Todd and Wolpin, 2003). However, as we do not have a complete set of preschool information and early school experience, we face a missing variable problem when we specify the relationship between pupil performance and school resources. Standard approaches to overcome this problem are either to use value-added approaches by approximating the previous school and family background by lagged test scores, or by differencing out unobservables over time or across siblings. Data to follow these strategies are not available.

Our strategy for identifying the effect of school resources and teacher quality involves using a rich set of family background variables. The preferred empirical specification is as follows:

$$
\text { (1) } \mathrm{A}_{\mathrm{ij}}=\mathrm{a}+\mathrm{b} \mathbf{F}_{\mathrm{i}}+\mathrm{c}_{\mathrm{j}} \mathbf{S}_{\mathrm{j}}+\mathrm{d}_{\mathrm{j}} \mathbf{T}_{\mathrm{j}}+\mathrm{k} \mathbf{Z}_{\mathrm{j}}+\varepsilon_{\mathrm{i}}
$$

where $A_{i j}$ is the achievement ('score') for pupil $i$ in school $j$. The achievement measure is based on subject-specific marks from exams, as well as continuous teacher assessment ('marks awarded for classwork'), see details in section four. $\mathbf{F}_{i}$ is a vector of family background variables including parents' education, long-term income and wealth, unemployment history, measures of family structure and family status in terms of married/divorced, immigrant status etc. $\mathbf{S}_{j}$ is a vector of variables reflecting the quantity of school resources, including class size and teacher hours per class. $\mathbf{T}_{\mathrm{j}}$ is a vector of variables reflecting the quality of school resources, i.e. characteristics of the teacher staff (formal education of teachers, experience, gender and turnover). $\mathbf{Z}_{\mathbf{j}}$ measures the average 'ability' of the pupils in school $\mathrm{j}$, proxied by the average expected achievement conditional on family background predicted from an auxiliary regression of $\mathrm{A}_{\mathrm{i}}$ on $\mathbf{F}_{i}$. We also include variables reflecting the urbanity of the municipality the schools are situated in. This is because some of the variation in resource use is related to small schools in sparsely populated rural areas. 
Our focus is on the impact of school resources, i.e. the OLS estimates of $c_{j}$ and $d_{j}$ in (1). The major question is then whether $\mathbf{S}_{j}$ and $\mathbf{T}_{\mathrm{j}}$ are orthogonal to unobserved pupil characteristics, e.g. ability.

Consider first the estimates of resource quantity. Pupils tend to cluster nonrandomly in schools since parents sort in to neighbourhoods and school districts. If this process are sorting pupils with (dis)advantaged background into districts where schools have (low) high resource use, the effect of school resources on pupil achievement is upward biased. Peer effects, where pupils benefit from having clever schoolmates, are likely to reinforce this effect. On the other hand, municipalities may allocate resources in a compensatory way. Less resources are allocated to schools with pupils who are expected to perform well (for a given school environment) and more teacher hours are provided for schools with less 'able' children. ${ }^{4}$ Compensating resource allocation implies that a family characteristic that has a positive effect on achievement also has a negative effect on resource variables such as teacher hours per class. If this is the case, estimates of the effects of resources on performance without controlling for family background will be downward biased. Thus, while family sorting and peer effects are likely to bias the quantity resource effects upwards, compensatory resource allocation generates a downward bias. In the Norwegian context, we expect the latter to dominate.

The quality aspect of school resources may also be allocated across pupils in a nonrandom way, possibly implying biased estimates of $d_{j}$ in (1). It is reasonable to consider the quality aspect to be captured by teacher quality, including aspects not captured by observable teacher characteristics. If teachers sort in a non-random way - for instance that highly skilled teachers sort into schools with high performing pupils - we face the problem of distinguishing the effect of school input quality from the effects of pupil composition. ${ }^{5}$ The assortative mat(ch)ing between pupil ability and teacher qualifications may arise from two different processes; i) advantaged families move to school districts with highly qualified teachers, or ii) teachers move to neighbourhoods and school districts with high performing pupils. In either case, estimates of teacher quality that do not account for the assortative matching will clearly be biased.

Although our preferred specification includes both $\boldsymbol{F}_{\boldsymbol{i}}$ and $\boldsymbol{Z}_{j}$, we also report the estimates from specifications where family background characteristics are excluded.

\footnotetext{
${ }^{4}$ Some resources may also be allocated directly to individual pupils in need of extra resources. It is believed that such pupils are too few to have a sizeable effect on resources per pupil measured at the school level.

${ }^{5}$ See Bonesrønning, Falch and Strøm (2003) for an analysis of teacher sorting in Norwegian upper secondary schools.
} 
Comparing the two sets of estimates, we can study how the effects of school resources and school quality are biased when controls for pupil composition are not included, due to pupil sorting across schools, compensatory resource allocation and assortative matching of teachers and pupils.

Finally, our main achievement measure comprises subject-specific marks awarded for classwork ('continuous assessment') set by the pupils' teacher. A potential problem arises if teachers are influenced by pupil composition of the class or school when marks are set. ${ }^{6}$ Teachers may have in mind that the distribution of marks within the class should not deviate too much from a "standard" distribution. This will, all else equal, make it more difficult to obtain good marks in a class where the average performance is high. Hence, relative marking by teachers can bias the effect of school resource use on pupils. The direction and magnitude of this bias may depend on the degree of relative marking and the degree of pupil sorting and compensatory resource allocation. In any case, it is important to include school average pupil characteristics to account for the possibility of relative marking.

We investigate the occurrence of relative marking by estimating (1) on achievements in national exams and comparing with estimates using marks (in the same subjects) based on continuous assessment. Using exam results only involves some drawbacks. First, since exams are given in single subjects only and not to the complete set of eleven subjects, we will have to compare exam results and marks awarded for classwork for individual subjects. This will tend to bias downward the effect of resources due to measurement error; since our resource use variables such as teacher hours per pupil are not connected to individual subjects. Further, exams could possibly contain more noise (but avoid relative marking) than marks for classwork, since they are based on a single test, while marks for classwork presumably are based on continuous testing throughout the school year. Consequently, the precision of the estimates based on exam results will be lower.

Although the main indicator of resource quantity is teacher hours per pupil, we report separate estimates for class size and teacher hours per class. We also test the hypothesis that attending a school with limited resources is likely to be particularly harmful to pupils with a disadvantaged background, by including an interaction term between school resources and predicted achievement based on family characteristics. Finally, we investigate if school resource effects differ across subjects.

\footnotetext{
${ }^{6}$ See Bonesrønning (2004) for marking practices in Norway at the high school level, and Møen and Tjelta (2004) for the importance of relative marking for accepting students to a university based on high school marks from different schools.
} 


\section{Data sources, sample and variable construction}

Our sample covers all pupils who completed compulsory education in Norway $\left(10^{\text {th }}\right.$ grade in the lower secondary school) in 2002 and 2003. We use three types of data, assembled from matching of a large number of administrative registers: Individual marks by subject, individual characteristics and family background variables, and school-level measures of resource use and teacher characteristics.

\section{Marks and school identification}

Data collected by the Norwegian Board of Education, contains information on which school the individual graduated from, and individual marks by subject. Pupils are awarded marks in eleven subjects. In all subjects, marks are awarded for classwork. In addition, all pupils are tested by a written exam in Norwegian, English or mathematics, and by an oral exam in one subject. The mark for a subject is the average of marks given for classwork and exam (where applicable). With two exams and eleven subjects, a little less than ten percent of the marks come from exams. Marks are awarded on a scale from 1 to 6 , with 6 as the highest. Table 1 shows the distribution of marks for a typical subject for the two cohorts.

Based on marks awarded in individual subjects, we construct a summary measure of total grade points. It is not obvious how individual marks should be aggregated, as some subjects are likely to provide more information about overall competence than others. Thus, giving equal weight to e.g. mathematics and home economics may not be the most adequate. We have chosen a weighting based on the allocation of teaching hours given throughout the ten years of compulsory schooling. (Weighting based on the teaching hours for lower secondary school $\left(8^{\text {th }}-10^{\text {th }}\right.$ grade $)$ provides very similar results. $)$

We have information on marks for more than 55,000 individuals per cohort. Around 4.5 percent are excluded from the sample; mainly due to missing information of family background, but also because they have too few marks or information on which school they attended is missing. Missing information on school characteristics removes around nine percent of the schools from the sample (but these are mainly small schools, thus few individuals are removed). 


\section{School characteristics}

Teacher hours, pupils and classes. Yearly school level information on (i) the number of pupils by grade (ii) the number of classes by grade, and (iii) the total hours of instruction for grade 8-10 are collected from the Norwegian Compulsory School Information System.

Instruction typically takes place within classes, but the number of teachers occupied with pupils belonging to a given class varies across subjects, classes, grades and schools. Teacher hours during a school year $(T H)$, relative to the number of pupils $(P)$, constitute an overall measure of instruction resources. This measure can be decomposed into teacher hours per class $(C)$ and number of classes per pupil, i.e.

(2) $\frac{T H}{P}=\frac{T H}{C} \times \frac{C}{P}$

Teacher intensity, (TH/P), is increased by smaller classes and more teacher hours per class. The three variables in (2) are constructed as averages of the three years prior to graduation, to reflect teacher input during the whole period the pupil attended lower secondary school.

Table 2 and Figure 1 and 2 illustrate a number of important features of variation in teacher input relative to the number of pupils. First, class size is (of course) closely related to cohort size and a huge part of the overall variation is found in schools with only one class per grade. 25 percent of the schools have less than 12 pupils per class, see Table 2. Sparsely populated areas explain class size below 15. The relationship in Figure 1 between average class size and number of pupils contains the familiar discontinuity around 30, 60, 90 etc. reflecting regulations on maximum class size. Second, teacher hours per class are not closely related to school size. There are some indications that hours per class are increasing with size and the variation is larger among small schools, see Figure 2. Third, the variation in the overall measure 'teacher hours per pupil' is huge, and completely dominated by few pupils per class in the smallest schools, see Table 2. Although the variation in teacher intensity is considerably lower among schools with more than one class per grade, the 90-10 differential in teacher hours per pupil is nearly 50 percent. Larger schools have less teacher hours per pupil, partly driven by the larger class size.

Teacher qualifications, turnover, age profile and gender composition. The teacher statistics enables us to construct measures reflecting the level of formal qualifications, age profile, gender composition and turnover of the teacher staff. Unfortunately, teacher 
characteristics are based on the total staff, i.e. not matched to grades or classes in which the teachers work, and private schools are not included. We include as explanatory variables the share of teachers without formal teacher qualifications ('unskilled'), the share of teachers with education at higher university level ('high-skilled') and a dummy variable indicating whether the head teacher has education at higher university level. Annual teacher flows in and out of each school can be identified, although not by grade affiliation. For each year, we calculate the churning rate, i.e. the sum of hirings and separations in excess of changes in the number of teachers employed, divided by the average number of teachers. The age and gender distributions of each school's teacher staff is measured by the fraction of teachers below age 30 and the proportion of females. All these variables are calculated as averages over the three years prior to graduation.

Urbanicity. Regional effects may affect our estimates in several ways. There may be regional differences in achievement levels (given family background), e.g. between urban and rural areas. To the extent that these differences affect resource allocation, one should control for region in the estimations. There may also be regional norms for setting marks. However, a substantial share of the "exogenous" variation in resource use is associated with regional differences. Some of the variation in class size relates to differences in population density, although this effect is mitigated when we exclude small schools from the sample. Including county fixed effects may also ignore part of the "administrative" variation in resource use. For a substantial number of pupils (and schools), the county is the administrative level at which school resources are allocated (typically in the capital Oslo). We have therefore chosen to control for regional effects by including dummies reflecting Statistics Norway's urbanicity classification of municipalities (seven categories).

We exclude schools with less than two classes per grade. This restriction is partly motivated by policy relevance. Reduction in standard class size towards a level below 20 is unlikely and increasing decentralization of schools involving smaller classes is hardly an issue. Our estimated effects are likely to be driven by variation in school size if we include all schools. The school size restriction removes around half of the schools and 15 percent of the pupils from the sample. Our estimating sample thus consists of 82000 pupils from around 550 schools.

\section{Pupil characteristics and family background}

The register data contain detailed information on pupil and family characteristics along a number of dimensions. All variables are constructed for the year the pupil graduates. 
Demographic information and family structure. We include dummy variables for the pupil's gender, quarter of birth (given graduation in the year they turn 16) and graduation in years earlier than expected from their age. Parents' marital status is measured by means of dummies reflecting whether they are married (to each other), cohabitants, separated, divorced or neither of these, and dummy variables indicating whether the father and/or mother is unknown. The age of the mother and father at the birth of their first child is represented by dummy variables reflecting age intervals. A detailed set of dummies reflects the number of full siblings, the number of half siblings and the rank in the birth order (of full siblings).

Parents' education. Educational attainment is classified into four categories: Lower secondary, upper secondary, lower tertiary and higher tertiary education. Based on this classification, we construct dummy variables for all combinations of father's and mother's education.

Immigrant status. Pupils with both parents born abroad are classified as immigrants. We distinguish between 15 countries/regions of origin by means of dummy variables. Age at immigration for the pupil is defined by intervals distinguishing between those born in Norway or immigrated before they were three years old, and those who immigrated when they were 3$5,5-7,7-9,9-11,11-13$ or 13 years or more.

Economic resources, unemployment, disability pension and social assistance. As the permanent economic resources of the family are more important than current income during the final school years, family income is defined as the sum of the father's and the mother's taxable labour income during the last ten years (regardless of marital status). Dummy variables reflect the position (quintile) in the family income distribution.

Family wealth for the pupil is defined as the sum of the father's and the mother's individual taxable wealth for the year prior to graduation. Since wealth typically increases over the major part of the life cycle, we construct age-specific wealth distributions, where we divide families into five-year age intervals based on the average age of the parents. Dummy variables reflect whether the family belongs to one of the upper four deciles of its age-specific wealth distribution. (A majority of families have negative taxable wealth. The tax value of housing, which is most common non-financial asset, is far below market value. Negative taxable wealth is reported as zero.)

The parents' unemployment records are used to construct variables for the incidence of unemployment during the ten years prior to the time of pupil's graduation. We ignore short unemployment spells and define a person to be unemployed if he or she was registered as unemployed for at least three months of a calendar year. We construct dummy variables, 
separately for mother and father, for unemployment in the graduation year, and for unemployment one, two, three, four and five or more years during the ten-year period prior to graduation. Similarly, we construct variables indicating the receipt of disability pension and social assistance. We define a person to be on disability pension if he or she received disability pensions for more than six months of the calendar year. Our criterion for defining a person as receiving social assistance is that he or she received at least $\mathrm{Nkr} 20,000$ (approx $€$ $2,500)$ in a given year. Dummy variables for disability pensions and social assistance are constructed in the same manner as for unemployment.

\section{How much of the variation in school results can be explained by family characteristics?}

A major concern is that school inputs partly reflect the composition of pupils. The family characteristics serve the role of controlling for differences in abilities across schools, such that the effects of school resources can be given an "all else equal" interpretation. Below, we briefly review the estimated relationships between family background variables and individual achievement.

We estimate equation (1) above, with only the vector of family background variables included. The set of family characteristics 'explains' close to one third of individual variation in achievement. This is substantial compared to a specification with only school fixed effects included, which has an R-squared of 0.04. Thus family background is a much more powerful predictor of pupil achievement than is school attended.

Individual grade points are highly correlated with parental education, positively related to economic resources of the family, lower if parents have experienced unemployment or received social benefits, higher for pupils with united parents and also related to age (quarter of birth), number of siblings and birth order. Non-Western immigrants who are born in Norway, or arrived before school start, achieve on average approximately the same grade points as other pupils with comparable parental education and economic resources at home. Girls outperform boys. The gender difference amounts to almost half a point per subject.

Table 3 displays the contribution of different sets of variables to explaining the variation in individual school results. A simple gender dummy specification 'explains' about 6 percent of the overall variation in grade points. Of other family characteristics, parents' education is by far the most important. Family structure also 'explains' a non-negligible part of the. At the margin, immigrant status does not contribute substantially, but given the relatively few immigrants the partial contribution is not negligible. Parental earnings and wealth do matter, even at the margin when parental education and family structure are 
included as controls. Finally, information on parental unemployment, disability pension and social assistance received by mother and father during the last five years provides no significant marginal contribution to the explained variation, but the partial contribution (when no other controls are included) is substantial.

\section{Results}

\section{Main results}

Table 4 displays the main results concerning the relationship between pupil achievement and school resources. Column (1) reports estimates without family background controls and suggests two important findings. On the one hand, achievement seems to be hurt if the pupil attends a school with a high fraction of unskilled teachers and gain from more high-skilled teachers. More female teachers seem to have a positive effect. On the other hand, more teacher input in terms of hours per pupil is associated with less favourable pupil performance. ${ }^{7}$ Thus, teacher quality seems to be beneficial, but teacher intensity in terms of hours per pupil is apparently detrimental to achievement.

These patterns are dramatically changed when family background controls are included, see column (2). First, inclusion of family controls flips the sign of quantitative school resources from significantly negative to positive, illustrating nicely the compensating resource allocation. More teacher hours per pupil do improve pupil performance, as the positive estimate is statistically significant. The average effect, 0.956 , reported in column (2) is not large. The predicted achievement differential, all else equal, between a pupil graduating from a school at the $90^{\text {th }}$ and one from a school at the $10^{\text {th }}$ percentile in the distribution of 'teacher hours per pupil', is about 0.37 . Thus, pupils at a school with more teacher hours per pupil are - on average - estimated to gain an increase in achievement of 0.37 points. This amounts to about one third of a mark in one of eleven subjects (where the range is 1 to 6). The standard deviation the achievement measure is 9.2 , so the estimate suggests that teacher input measured by hours of instruction has a limited effect, although not negligible.

Second, the impact from teacher qualifications change considerably when we add in family controls. While the effects of high-skilled teachers disappear, the negative effect of a large unskilled staff in secondary schools is drastically reduced, with a p-value of 0.055 . Moreover, a larger fraction of female teachers is now associated with less favourable pupil

\footnotetext{
${ }^{7}$ Note that teachers' characteristics are measured at the school level and thereby of less interest for pupils in combined $1^{\text {st }}-10^{\text {th }}$ grade schools.
} 
performance, although not significant. These findings reflect the sorting of teachers across schools and neighbourhoods.

Table 5 reports correlations between family background, measured as the predicted grade points from a regression where only family background variables are included, and various school characteristics. There are clear indications of compensating resource allocation: Pupils with advantaged background tend to attend schools with relatively few resources, measured by teacher hours per pupil, teacher hours per class and or by pupils per class. There are also signs of assortative matching of teachers and pupils: Pupils with advantaged background tend to attend schools with more qualified teachers. Female teachers are also overrepresented in schools with pupils with advantaged backgrounds. Also note that there is a positive correlation between variables of teacher intensity and the share of teachers without formal qualifications. This may be an indication that increases in teacher intensity take place by hiring assistant teachers without formal teacher education.

Thus, failure to control for pupils composition is likely to create severe biases in the estimates of teacher characteristics effects. Non-random matching emerge because well qualified teachers move to schools in advantaged neighbourhoods or because wealthy, welleducated families buy houses located close to schools with qualified teachers. As the mobility of teachers across schools is likely to be higher than the residential mobility of families, we expect the former to dominate.

There seems to be no effect of pupil composition, as the average family background of the school's pupils has negligible impact on achievement. Note, however, that this reduced form relationship may comprise numerous effects, possibly pulling in different directions, see previous discussion in section 3 and further results below.

The results in column (2) Table 5, suggest that effects of school resources are weak. It also explains a limited part of the variation across schools (i.e. school-specific factors). If we estimate equation (1) where school fixed effects replace the observed school characteristics, we get an $\mathrm{R}^{2}$ equal to 0.3197 . The model without any school variables at all reports a $\mathrm{R}^{2}$ $=0.3012$. Since our preferred equation has an $\mathrm{R}^{2}=0.3024$, only $6 \%$ of the variation due to school characteristics is accounted for by our observed school characteristics. Evidently, other school characteristics like unobserved teacher quality, organisational practices, instruction practices or management etc. are more important. ${ }^{8}$

\footnotetext{
${ }^{8}$ If urbanicity is included among the observed school characteristics, we explain $11.7 \%$ (rather than $6 \%$ ) of the conditional between school variance.
} 
Both in the public discussion and in the research literature, it is commonly argued that attending a school with limited resources is likely to be particularly harmful to 'lowperforming students'. As we have no information on previous performance or ability, we test this claim by letting the effect of teacher hours per pupil vary with family background. Rather than picking a number of family characteristics (e.g. parental education), we calculate the predicted performance of each pupil from a regression model without school characteristics, cut the distribution in five and let the 'teacher hours per pupil' effect vary across groups, see column (3). We find no evidence in support of the view that more resources are particularly important to low-ability students. On the contrary, the marginal effect of more teacher hours per pupil is higher among pupils from advantaged families. The point estimates are 0.72 and 1.11 for the lowest and highest quintiles, respectively. However, in light of the standard errors we cannot conclude that high-ability students are more affected.

The results in columns (1) - (3) Table 4 are all based on the composite measure 'teacher hours per pupil', which can easily be split into 'teacher hours per class' and 'pupils per class', as in column (4). It turns out that both input measures have the expected sign and the equal-effect-restriction is clearly not rejected. The class-size effect, however, is not statistically significant. In terms of predicted performance, the 90-10 differential in teacher per class is associated with an achievement differential of 0.28 points.

Regional effects are accounted for by means of six urbanicity dummies, explained in section four. A need for more detailed regional controls can be questioned. In addition to potential patterns in school resources across region, there may be relative marking within local areas. On the other hand, a substantial share of the "exogenous" variation in resource use is due to different priorities across local authorities. Some municipalities spend more money on schools than others. However, if we include nineteen county fixed effects, the qualitative results reported in column (1) - (3) remain unchanged (results are available upon request), although the estimates are somewhat lower and less precise. ${ }^{9}$

\section{Single tests versus continuous assessment}

\footnotetext{
${ }^{9}$ As we have data for two consecutive cohorts, it is even possible to estimate the main parameter of interest with school fixed effects included. In a model similar to (2) in Table 4, the effect of 'teacher hours per pupil' is positive, but low and not significant, $0.416(1.23)$. Access to more cohorts are necessary if this strategy is used to identify causal effect, and it is far from obvious that school fixed effects model is a remedy to handle e.g. compensatory resource allocation.
} 
The achievement measure used so far is a combination of marks awarded for classwork (on the basis of continuous assessment) and exam (i.e. single test) performance. The weight on the former, where the teacher sets the marks based on continuous assessment, is more than 0.9. Scores from the anonymous exams count for less than ten per cent. Table 6 reports the effects on exam scores and marks awarded for classwork, respectively, using an ordered probit model (since the outcome measure takes a value 1 to 6 for each pupil). For both types of achievement measures, each pupil has a score in Norwegian, Mathematics or English since they typically takes one exam test only. Thus, the effects are on the average achievement in these three subjects. Consider first the exam result with the composite resources measure in column (1). While a negative effect is found for the fraction of unskilled teachers, teacher hours per pupil does not seem to matter at all. The median fraction of unskilled teachers is only 0.022 , and the difference between the $10^{\text {th }}$ percentile (i.e. zero) and the $90^{\text {th }}$ percentile (0.063) translate to a predicted propensity score differential of $0.063 *-1.242=-0.078$. In terms of probabilities, this reflects a difference of 4.0 percent in the probability of attaining mark 4 or better.

Exam scores are correlated with pupil composition, as pupils who go to schools with schoolmates who have an advantaged background perform better. The positive association between individual achievement and the predicted score of schoolmates is likely to reflect sorting on unobserved characteristics that correlates with family background. It may also arise from peer effects.

The effects on marks from continuous assessment by the teacher in column (2) show a different pattern, except for unskilled teachers which has a similar negative effect. Teacher hours per pupil has a positive effect, but it is not significant by common standards ( $p$-value is 0.099). The effect of pupil composition is strikingly different, i.e. it disappears, when we look at marks awarded for classwork. Sorting and peer-group effects should be equally important when achievement is measured by continuous assessments, compared to exams. Consequently, there seems to be a counteracting effect which nets out the total. Relative marking is a likely candidate as this would tend to give a lower mark, if the pupil have schoolmates from an advantaged background (given own family background). Similarly, if a pupil has schoolmates who on average have less qualifications, it is more likely that she gets a positive assessment from her teacher.

Separate effects of class size and teacher hours per class are reported in column (3) and (4), Table 6. Earlier patterns are recognized as no effect is found for class size. There seems to be a positive effect of teacher hours per class for marks awarded for classwork, but 
the effect is not significant at a 5 percent level (p-value of 0.065). It should be noted that we estimate the effect of average teacher input across grades $\left(8-10^{\text {th }}\right)$ and subjects, which may bias the impact downwards. If teacher input varies between subjects, the effects on the three main subjects in Table 6 will be biased downwards and the standard errors will be higher than for effects on average achievement.

\section{Effects across subjects}

Although teacher resources are not measured by subject, it can be instructive to see whether the effects of teacher hours per pupil differ across subjects. Table 7 reports the effects on subject achievement by subject, based on marks awarded for classwork (or the average of the mark awarded for classwork and the mark for exam when applicable). The fraction of unskilled teachers has a negative effect on achievement in all subjects, but the effect is not significant for Norwegian, English and Physical education, see Table 7. As the $90^{\text {th }}-10^{\text {th }}$ percentile differential of fraction unskilled teachers is 0.063 , pupils in school with 'many' unskilled teachers workers achieve around 0.07 lower marks than those in schools without unskilled teachers (recall the scale is 1-6). Positive and significant effects of teacher intensity is found for Mathematics and, surprisingly, for Physical education. There is a positive but insignificant effect for Social science, and no effect in English. Since the largest effect is found for Physical education, one might question the causal interpretation of the teacher intensity effect on average achievement in Table 4. It should be kept in mind that effects on single subjects are downward bias from measurement error, simply because teacher hours per pupil is an average which do not reflect the teacher input directed towards a specific subject.

\section{Concluding remarks}

Behavioural responses from school authorities, teachers and parents may imply that pupils and resources are not randomly distributed across schools, and complicate the identification of the effects of school resources on pupil achievement This paper illustrates that these issues are not only of theoretical interest, but have substantial empirical relevance. In the present paper we use a very rich matched register dataset for pupils and schools for two complete cohorts of pupils in the Norwegian lower secondary school. The data allow for various tests of the relationship between pupil achievements and school resources. In particular, we focus on disentangling the effect of parental background and the effect of the quantity and quality of 
resources. In addition, we reveal the importance of compensating resource allocation by school authorities. Further, data on both national exams and on continuous class assessment offer an opportunity to test for relative marking by teachers.

Our results show that effects of school resources like teacher hours per pupil and staff skill level are modest, within the range of variation found in Norwegian lower secondary schools. We find no effects of class size, but pupils seem to benefit from more teacher hours per class. By comparing estimates for single tests and marks from continuous assessment, we find no effect of teacher intensity on exam scores. The different coefficients on pupil composition, i.e. the average predicted achievement among the pupil's schoolmates, for exam and marks awarded for classwork, suggest that relative marking is taking place. The lack of teacher input effects in subjects like English and Norwegian, combined with the strong effect in physical education, also suggest that (the variation in) these kind of school resources only explain a minor part of the variation in pupil achievement at age 16 . There is no indication that low-ability students gain more than others from extra resources at the school level. On the contrary, achievement among pupils from advantaged background is (insignificantly) more sensitive to changes in teacher hours per pupil. Finally, we clearly illustrate that pupil and teacher sorting are empirically important as the biases in the estimates of school resources are huge, if we do not control for pupil composition by means of a detailed set of family characteristics.

\section{References}

Angrist, J. and V. Lavy (1999). "Using Mainmonides' rule to estimate the effect of class size on scholasitic achievements", The Quarterly Journal of Economics, 114: 229-241.

Betts, J. R. (1996). “Do school resources matter only for older workers?”, Review of Economics and Statistics, Vol. 78, pp. 638-652.

Black, S., Devereux, P. and Salvanes, K. G. (2003). Why the apple doesn't fall far: Understanding Intergenerational Transmission of Human Capital”, NBER working paper no 10066. 
Bonesrønning, H. (1996): School Characteristics and Student Achievement: Evidence from Combined Upper Secondary Schools in Norway. Education Economics, Vol. 4, No. 2.

Bonesrønning, H. (2003): Class Size Effects on Student Achievement in Norway: Patterns and Explanations. Southern Economic Journal, 69(4), 952-965.

Bonesrønning, H. (2004a): The determinants of parental effort in education production: do parents respond to changes in class size? Economics of Education Review 23, 1-9.

Bonesrønning, H. (2004b) Can effective teacher behaviour be identified? Economics of Education Review 23 237-247.

Bonesrønning, H., Falch, T., and Strøm, B. (2003): Teacher Sorting, Teacher Quality, and Student Composition. European Economic Review, forthcoming

Browning, M. and Heinesen, E.(2003) "Class size, teacher hours and educational attainment", CAM Working paper 2003-15, University of Copenhagen.

Card, D. and Krueger, A. (1992). "Does School Quality Matter? Returns to Education and the Characteristics of Public Schools in the United States," Journal of Political Economy, vol. 100 (1), pp. 1-40.

Coleman, J. S. et al. (1966). Equality of Educational Opportunity. Washington DC: US GPO.

Dearden, L., Ferri, J. and Meghir, C. (2002).’The effect of school quality on educational attainment and wages", Review of Economics and Statistics, Vol. 84, pp. 1-20.

Dustmann, C. Rajan, N. and van Soest, A. (2003). "Class size, education and wages." Economic Journal, Vol. 113(1), pp. F99-F120.

Hanushek, E. A. (1996). "School resources and student performance”. In G. Burtless (ed.) Does money matter? The effect of school resources on student achievement and adult success. Washington D.C.: Brookings Institution. 
Hanushek, E. A. (2003). “The Failure of Input-Based Schooling Policies”, Economic Journal, Vol. 113 (February), pp. F64-F98.

Hanushek, E. A., Kain, J.F. and Rivkin, S. (1998). "Teachers, schools and achievements." NBER working paper no. 6691.

Hanushek, E. A., O'Brien, D. and Rivkin, S. (1998). “The Market for Teacher Quality.” Paper presented at the NBER Summer Institute 2004.

Heckman, J. J, Ichimura, H. and Todd, P. (1998): "Matching as an Econometric Evaluation Estimator," Review of Economic Studies, Vol. 65 (2). 261-94.

Hoxby, C. (2000). "Peer effects in the classroom”, NBER working paper No. 7867.

Krueger, A.B (1999): "Experimental Estimates of Education Production Functions," Quarterly Journal of Economics, 114, 497-532.

Krueger, A.B (2003). Economic Considerations and Class Size, Economic Journal, Vol. 113 (February), pp. F34-F63.

Krueger, A. and Lindahl, M. (2002) "The School's Need for Resources - A Report on the Importance of Small Classes," The Expert Group on Public Finance (ESO), Stockholm, May 2002 .

Lazear, E. (2001). 'Educational Production”, Quarterly Journal of Economics, 116: 777-803.

Machin, S. and McNally, S. (2003). "The literacy hour", mimeo, Center for Economics of Education, London School of Economics, London.

Møen, J. and M. Tjelta (2004); Do different schools grade similar students differently? An analysis of the relationship between school background and student performance at $\mathrm{NHH}$, mimeo. 
Rockoff, J. E. (2004). "The impact of individual teachers on student achievement: evidence from panel data", American Economic Review 94(2): 247-252.

Todd, P.E. and Wolpin, K. I. (2003). "On the specification and estimation of the production function for cognitive achievement.” Economic Journal, Vol. 113 (February), pp. F3-F33.

Wilson, K (2002): The effect of school quality on income, Economics Education Review, 21, $579-588$

Table 1. Marks in Norwegian (primary form, written) 2002 and 2003, percent

\begin{tabular}{lll}
\hline Mark & Exam & Classwork \\
\hline 1 & 0.7 & 0.4 \\
2 & 12.1 & 8.2 \\
3 & 35.2 & 28.0 \\
4 & 32.9 & 36.6 \\
5 & 16.6 & 24.3 \\
6 & 2.4 & 2.5 \\
\hline
\end{tabular}

Table 2. Class size and measures of teacher input.

\begin{tabular}{lllllll}
\hline & & \multicolumn{2}{l}{ Percentiles } & & & \\
\cline { 3 - 7 } & Mean & $\mathbf{9 0} \%$ & $\mathbf{7 5 \%}$ & $\mathbf{5 0} \%$ & $\mathbf{2 5} \mathbf{\%}$ & $\mathbf{1 0} \%$ \\
\hline All schools (n=1133) & & & & & & \\
Pupils / classes: & 18.7 & 26.9 & 25.3 & 22 & 12 & 5 \\
Teacher hours / classes: & 1829 & 2156 & 1971 & 1807 & 1660 & 1524 \\
Teacher hours / pupils: & 173.3 & 380 & 142.6 & 85.7 & 73.2 & 66.0 \\
& & & & & & \\
Medium-large schools (n=559) & & & & & & \\
Pupils / classes: & 24.6 & 27.6 & 26.5 & 25.1 & 23.6 & 21.2 \\
Teacher hours / classes: & 1857 & 2114 & 1963 & 1824 & 1720 & 1621 \\
Teacher hours / pupils: & 76.3 & 90.7 & 82.6 & 74.5 & 68.2 & 62.9 \\
\hline
\end{tabular}


Table 3. R-squared with different sets of individual and family background variables. Total, marginal and partial effects

\begin{tabular}{|c|c|c|c|c|}
\hline Pupil and family characteristics & Specification and controls & Total & Marginal & Partial \\
\hline \multirow[t]{2}{*}{ I. Gender } & Dummy-variable: Girl=1 & 0.06 & 0.06 & 0.06 \\
\hline & Educational attainment of mother and father (five & & & \\
\hline \multirow[t]{2}{*}{ II. Parental educational attainment } & groups, incl. missing), full interaction. & 0.23 & 0.17 & 0.17 \\
\hline & $\begin{array}{l}\text { Marital/co-habital status of the parents includes divor- } \\
\text { ced and separated, number of full siblings and half- }\end{array}$ & & & \\
\hline III. Family structure & $\begin{array}{l}\text { siblings. Birth quarter and order (among full siblings). } \\
\text { Country of origin (grouped). Age at immigration; }\end{array}$ & 0.28 & 0.05 & 0.12 \\
\hline IV. Immigrant status & {$[0-3),[3,6),[7,9),[9,11),[11,13)$ and $13+$} & 0.29 & 0.01 & 0.03 \\
\hline V. Economic resources & $\begin{array}{l}\text { Parental earnings during school years (age 6-15) and } \\
\text { financial wealth }\left(8^{\text {th }}, 9^{\text {th }} \text { and } 10^{\text {th }} \text { decile) }\right.\end{array}$ & 0.31 & 0.02 & 0.12 \\
\hline $\begin{array}{l}\text { VI. Parental unemployment disa- } \\
\text { bility pension and social assistance }\end{array}$ & $\begin{array}{l}\text { Parental unemployment, disability pension and social } \\
\text { assistance by } \mathrm{M} \text { and } \mathrm{F} \text { during the last five years. }\end{array}$ & 0.31 & 0.00 & 0.10 \\
\hline
\end{tabular}


Table 4. School resources and pupil achievement. Average across subjects.

\begin{tabular}{|c|c|c|c|c|}
\hline & (1) & (2) & (3) & (4) \\
\hline Combined primary and secondary school & $\begin{array}{l}-1.522 \\
(1.378)\end{array}$ & $\begin{array}{l}-1.766 \\
(1.021)\end{array}$ & $\begin{array}{l}-1.751 \\
(1.021)\end{array}$ & $\begin{array}{l}-1.706 \\
(1.042)\end{array}$ \\
\hline Unskilled teachers (fraction) sec.school & $\begin{array}{l}-14.143 \\
(3.100)^{* *}\end{array}$ & $\begin{array}{l}-4.792 \\
(2.493)\end{array}$ & $\begin{array}{l}-4.795 \\
(2.494)\end{array}$ & $\begin{array}{l}-4.480 \\
(2.505)\end{array}$ \\
\hline Unskilled teachers (fraction)comb.school & $\begin{array}{l}4.992 \\
(8.389)\end{array}$ & $\begin{array}{l}7.249 \\
(6.497)\end{array}$ & $\begin{array}{l}7.345 \\
(6.496)\end{array}$ & $\begin{array}{l}7.336 \\
(6.466)\end{array}$ \\
\hline High-skilled teachers(fraction)sec.school & $\begin{array}{l}4.303 \\
(1.509)^{* *}\end{array}$ & $\begin{array}{l}-0.988 \\
(1.014)\end{array}$ & $\begin{array}{l}-0.964 \\
(1.012)\end{array}$ & $\begin{array}{l}-0.997 \\
(1.014)\end{array}$ \\
\hline $\begin{array}{l}\text { High-skilled teachers } \\
\text { (fraction)comb.school }\end{array}$ & $\begin{array}{l}-2.840 \\
(6.312)\end{array}$ & $\begin{array}{l}-0.322 \\
(4.358)\end{array}$ & $\begin{array}{l}-0.356 \\
(4.345)\end{array}$ & $\begin{array}{l}-0.561 \\
(4.390)\end{array}$ \\
\hline $\begin{array}{l}\text { Female teachers } \\
\text { (fraction) sec.school }\end{array}$ & $\begin{array}{l}3.258 \\
(1.085)^{* *}\end{array}$ & $\begin{array}{l}-1.437 \\
(0.743)\end{array}$ & $\begin{array}{l}-1.443 \\
(0.743)\end{array}$ & $\begin{array}{l}-1.438 \\
(0.742)\end{array}$ \\
\hline $\begin{array}{l}\text { Female teachers } \\
(\text { fraction) comb.school } \\
\text { Young teachers } \\
(\text { fraction age }<30) \text { secondary school } \\
\text { Young teachers } \\
(\text { fraction age }<30) \text { combined school }\end{array}$ & $\begin{array}{l}6.103 \\
(2.079)^{* *} \\
-2.154 \\
(1.141) \\
0.072 \\
(2.436)\end{array}$ & $\begin{array}{l}1.834 \\
(1.458) \\
-0.252 \\
(0.922) \\
0.734 \\
(2.363)\end{array}$ & $\begin{array}{l}1.807 \\
(1.458) \\
-0.233 \\
(0.922) \\
0.779 \\
(2.362)\end{array}$ & $\begin{array}{l}1.774 \\
(1.471) \\
-0.255 \\
(0.925) \\
0.713 \\
(2.357)\end{array}$ \\
\hline Teacher turnover rate, sec.school & $\begin{array}{l}0.940 \\
(0.853)\end{array}$ & $\begin{array}{l}0.360 \\
(0.662)\end{array}$ & $\begin{array}{l}0.349 \\
(0.662)\end{array}$ & $\begin{array}{l}0.369 \\
(0.662)\end{array}$ \\
\hline Teacher turnover rate, combined school & $\begin{array}{l}-3.432 \\
(2.701)\end{array}$ & $\begin{array}{l}-1.483 \\
(2.342)\end{array}$ & $\begin{array}{l}-1.504 \\
(2.338)\end{array}$ & $\begin{array}{l}-1.491 \\
(2.334)\end{array}$ \\
\hline $\begin{array}{l}\text { School average of } \operatorname{Pred}(\mathrm{Aij} \mid \mathrm{Fj}) \text { in second } \\
\text { quintile }\end{array}$ & & $\begin{array}{l}-0.100 \\
(0.168)\end{array}$ & $\begin{array}{l}-0.107 \\
(0.168)\end{array}$ & $\begin{array}{l}-0.094 \\
(0.168)\end{array}$ \\
\hline $\begin{array}{l}\text { School average of } \operatorname{Pred}(\mathrm{Aij} \mid \mathrm{Fj}) \text { in third } \\
\text { quintile }\end{array}$ & & $\begin{array}{l}-0.307 \\
(0.170)\end{array}$ & $\begin{array}{l}-0.316 \\
(0.169)\end{array}$ & $\begin{array}{l}-0.304 \\
(0.170)\end{array}$ \\
\hline $\begin{array}{l}\text { School average of } \operatorname{Pred}(\mathrm{Aij} \mid \mathrm{Fj}) \text { in fourth } \\
\text { quintile }\end{array}$ & & $\begin{array}{l}0.013 \\
(0.167)\end{array}$ & $\begin{array}{l}0.005 \\
(0.167)\end{array}$ & $\begin{array}{l}0.015 \\
(0.167)\end{array}$ \\
\hline $\begin{array}{l}\text { School average of } \operatorname{Pred}(\mathrm{Aij} \mid \mathrm{Fj}) \text { in fifth } \\
\text { quintile }\end{array}$ & & $\begin{array}{l}-0.077 \\
(0.194)\end{array}$ & $\begin{array}{l}-0.075 \\
(0.193)\end{array}$ & $\begin{array}{l}-0.072 \\
(0.195)\end{array}$ \\
\hline Ln (Teacher hours/ Pupils) & $\begin{array}{l}-1.833 \\
(0.612)^{* *}\end{array}$ & $\begin{array}{l}0.956 \\
(0.405)^{*}\end{array}$ & & \\
\hline$* \operatorname{Pred}(\mathrm{Aij} \mid \mathrm{Fj})$ in first quintile & & & $\begin{array}{l}0.717 \\
(0.409)\end{array}$ & \\
\hline$* \operatorname{Pred}(\mathrm{Aij} \mid \mathrm{Fj})$ in second quintile & & & $\begin{array}{l}0.837 \\
(0.406)^{*}\end{array}$ & \\
\hline$* \operatorname{Pred}(\mathrm{Aij} \mid \mathrm{Fj})$ in third quintile & & & $\begin{array}{l}0.956 \\
(0.404)^{*}\end{array}$ & \\
\hline$* \operatorname{Pred}(\mathrm{Aij} \mid \mathrm{Fj})$ in fourth quintile & & & $\begin{array}{l}1.070 \\
(0.405)^{* *}\end{array}$ & \\
\hline$* \operatorname{Pred}(\mathrm{Aij} \mid \mathrm{Fj})$ in fifth quintile & & & $\begin{array}{l}1.112 \\
(0.404)^{* *}\end{array}$ & \\
\hline Ln (Teacher hours/ Classes) & & & & $\begin{array}{l}1.055 \\
(0.476)^{*}\end{array}$ \\
\hline Ln (Pupils/Classes) & & & & $\begin{array}{l}-0.789 \\
(0.577)\end{array}$ \\
\hline Constant & $\begin{array}{l}48.000 \\
(2.656)^{* *}\end{array}$ & $\begin{array}{l}38.785 \\
(1.824)^{* *}\end{array}$ & $\begin{array}{l}39.031 \\
(1.826)^{* *}\end{array}$ & $\begin{array}{l}37.526 \\
(3.684)^{* *}\end{array}$ \\
\hline Other controls & \multicolumn{4}{|c|}{$\begin{array}{l}\text { Examination in Norwegian, head teacher post-graduate education, year dummy } \\
\text { urbanicity dummies. }\end{array}$} \\
\hline Family backgr. char & $\mathrm{NO}$ & YES & YES & YES \\
\hline $\begin{array}{l}\text { Observations } \\
\text { R-squared }\end{array}$ & $\begin{array}{l}82,783 \\
0.01\end{array}$ & $\begin{array}{l}82,783 \\
0.30\end{array}$ & $\begin{array}{l}82,783 \\
0.30\end{array}$ & $\begin{array}{l}82,783 \\
0.30\end{array}$ \\
\hline
\end{tabular}

Note: Robust standard errors by means of clustering on school. */** denotes significance on 5/1 percent level. 


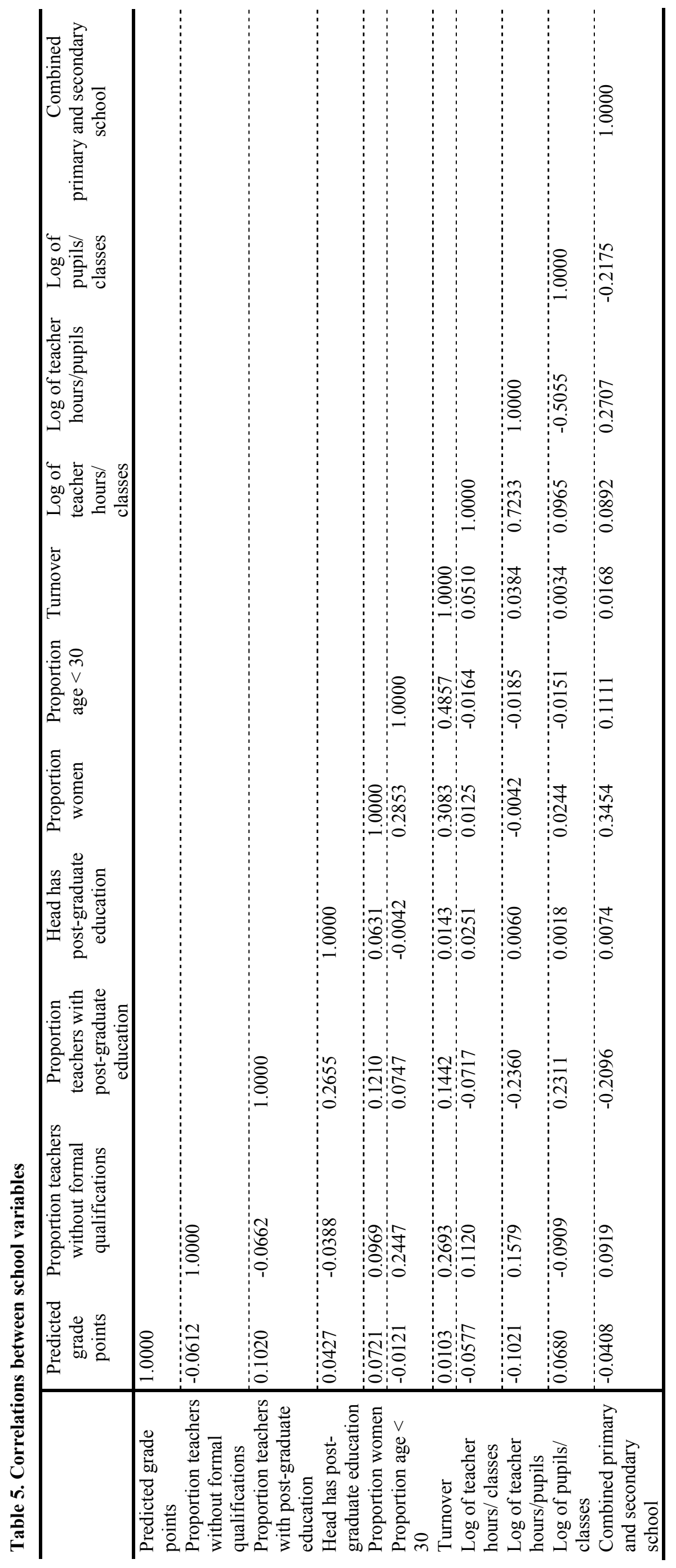


Table 6. Effects on exam performance and continuous assessment. Ordered probit coefficients.

Selected parameters.

\begin{tabular}{|c|c|c|c|c|}
\hline & Exam marks & $\begin{array}{l}\text { Marks awarded } \\
\text { for classwork }\end{array}$ & Exam marks & $\begin{array}{l}\text { Marks awarded } \\
\text { for classwork }\end{array}$ \\
\hline & (1) & $(2)$ & (3) & (4) \\
\hline $\begin{array}{l}\text { Unskilled teachers } \\
\text { (fraction)sec.school } \\
\text { High-skilled teachers } \\
\text { (fraction) sec.school }\end{array}$ & $\begin{array}{l}-1.242 * * \\
(0.306) \\
-0.229 \\
(0.130)\end{array}$ & $\begin{array}{l}-0.677 * * \\
(0.292) \\
-0.123 \\
(0.126)\end{array}$ & $\begin{array}{l}-1.284 * * \\
(0.300) \\
-0.224 \\
(0.130)\end{array}$ & $\begin{array}{l}-0.681 * * \\
(0.293) \\
-0.136 \\
(0.126)\end{array}$ \\
\hline $\begin{array}{l}\text { School average of } \operatorname{Pred}(\mathrm{Aij} \mid \mathrm{Fj}) \\
\text { in second quintile }\end{array}$ & $\begin{array}{l}-0.030 \\
(0.019)\end{array}$ & $\begin{array}{l}-0.032 \\
(0.021)\end{array}$ & $\begin{array}{l}0.004 \\
(0.022)\end{array}$ & $\begin{array}{l}-0.032 \\
(0.021)\end{array}$ \\
\hline $\begin{array}{l}\text { School average of } \operatorname{Pred}(\mathrm{Aij} \mid \mathrm{Fj}) \\
\text { in third quintile }\end{array}$ & $\begin{array}{l}0.047 * \\
(0.021)\end{array}$ & $\begin{array}{l}-0.028 \\
(0.021)\end{array}$ & $\begin{array}{l}0.046^{*} \\
(0.021)\end{array}$ & $\begin{array}{l}-0.027 \\
(0.021)\end{array}$ \\
\hline $\begin{array}{l}\text { School average of } \operatorname{Pred}(\mathrm{Aij} \mid \mathrm{Fj}) \\
\text { in fourth quintile }\end{array}$ & $\begin{array}{l}0.080 * * \\
(0.022)\end{array}$ & $\begin{array}{l}0.007 \\
(0.023)\end{array}$ & $\begin{array}{l}0.080 * * \\
(0.023)\end{array}$ & $\begin{array}{l}0.005 \\
(0.023)\end{array}$ \\
\hline $\begin{array}{l}\text { School average of Pred(Aij|Fj) } \\
\text { in fifth quintile }\end{array}$ & $\begin{array}{l}0.139 * * \\
(0.024)\end{array}$ & $\begin{array}{l}-0.001 \\
(0.023)\end{array}$ & $\begin{array}{l}0.142 * * \\
(0.024)\end{array}$ & $\begin{array}{l}-0.004 \\
(0.022)\end{array}$ \\
\hline Ln (Teacher hours/ Pupils) & $\begin{array}{l}-0.001 \\
(0.056)\end{array}$ & $\begin{array}{l}0.084 \\
(0.051)\end{array}$ & & \\
\hline Ln (Teacher hours/ Classes) & & & $\begin{array}{l}0.015 \\
(0.065)\end{array}$ & $\begin{array}{l}0.109 \\
(0.059)\end{array}$ \\
\hline Ln (Pupils/Classes) & & & $\begin{array}{l}-0.020 \\
(0.022)\end{array}$ & $\begin{array}{l}-0.005 \\
(0.058)\end{array}$ \\
\hline Other controls & \multicolumn{4}{|c|}{$\begin{array}{l}\text { Family background characteristics, head teacher post-graduate education, } \\
\text { year dummy, urbanicity dummies, subject dummies for exam columns. }\end{array}$} \\
\hline Observations & 81,684 & 81,639 & 81,684 & 81,639 \\
\hline
\end{tabular}

Note: Robust standard errors by means of clustering on school.

* denotes significance on 5 percent level. ** denotes significance on 1 percent level 
Table 7. School resource effects across subjects. Selected parameters.

\begin{tabular}{|c|c|c|c|c|c|}
\hline & Norwegian & Mathematics & English & $\begin{array}{l}\text { Social } \\
\text { science }\end{array}$ & $\begin{array}{l}\text { Physical } \\
\text { education }\end{array}$ \\
\hline $\begin{array}{l}\text { Unskilled teachers } \\
\text { (fraction)sec.school }\end{array}$ & $\begin{array}{l}-0.126 \\
(0.282)\end{array}$ & $\begin{array}{l}-0.956^{* *} \\
(0.257)\end{array}$ & $\begin{array}{l}-0.410 \\
(0.268)\end{array}$ & $\begin{array}{l}-0.808 * * \\
(0.292)\end{array}$ & $\begin{array}{l}-0.713 \\
(0.381)\end{array}$ \\
\hline $\begin{array}{l}\text { High-skilled teachers } \\
\text { (fraction) sec.school }\end{array}$ & $\begin{array}{l}-0.239 \\
(0.111)^{*}\end{array}$ & $\begin{array}{l}-0.119 \\
(0.114)\end{array}$ & $\begin{array}{l}-0.073 \\
(0.115)\end{array}$ & $\begin{array}{l}-0.175 \\
(0.125)\end{array}$ & $\begin{array}{l}0.121 \\
(0.155)\end{array}$ \\
\hline $\begin{array}{l}\text { School average of } \operatorname{Pred}(\mathrm{Aij} \mid \mathrm{Fj}) \\
\text { in second quintile }\end{array}$ & $\begin{array}{l}-0.030 \\
(0.019)\end{array}$ & $\begin{array}{l}0.037 \\
(0.021)\end{array}$ & $\begin{array}{l}-0.007 \\
(0.020)\end{array}$ & $\begin{array}{l}0.005 \\
(0.022)\end{array}$ & $\begin{array}{l}-0.024 \\
(0.028)\end{array}$ \\
\hline $\begin{array}{l}\text { School average of } \operatorname{Pred}(\mathrm{Aij} \mid \mathrm{Fj}) \\
\text { in third quintile }\end{array}$ & $\begin{array}{l}-0.051 * * \\
(0.019)\end{array}$ & $\begin{array}{l}0.022 \\
(0.021)\end{array}$ & $\begin{array}{l}0.018 \\
(0.020)\end{array}$ & $\begin{array}{l}-0.030 \\
(0.023)\end{array}$ & $\begin{array}{l}-0.058 * \\
(0.027)\end{array}$ \\
\hline $\begin{array}{l}\text { School average of } \operatorname{Pred}(\mathrm{Aij} \mid \mathrm{Fj}) \\
\text { in fourth quintile }\end{array}$ & $\begin{array}{l}-0.021 \\
(0.020)\end{array}$ & $\begin{array}{l}0.066 * * \\
(0.022)\end{array}$ & $\begin{array}{l}0.045^{*} \\
(0.020)\end{array}$ & $\begin{array}{l}-0.008 \\
(0.023)\end{array}$ & $\begin{array}{l}-0.029 \\
(0.027)\end{array}$ \\
\hline $\begin{array}{l}\text { School average of } \operatorname{Pred}(\mathrm{Aij} \mid \mathrm{Fj}) \\
\text { in fifth quintile }\end{array}$ & $\begin{array}{l}-0.045^{*} \\
(0.022)\end{array}$ & $\begin{array}{l}0.073 * * \\
(0.024)\end{array}$ & $\begin{array}{l}0.035 \\
(0.021)\end{array}$ & $\begin{array}{l}-0.046 \\
(0.026)\end{array}$ & $\begin{array}{l}-0.030 \\
(0.033)\end{array}$ \\
\hline Ln (Teacher hours/ Pupils) & $\begin{array}{l}0.054 \\
(0.043)\end{array}$ & $\begin{array}{l}0.113 * \\
(0.053)\end{array}$ & $\begin{array}{l}-0.005 \\
(0.047)\end{array}$ & $\begin{array}{l}0.084 \\
(0.052)\end{array}$ & $\begin{array}{l}0.131 * \\
(0.064)\end{array}$ \\
\hline Constant & $\begin{array}{l}3.636 \\
(0.197)\end{array}$ & $\begin{array}{l}3.018 \\
(0.238)\end{array}$ & $\begin{array}{l}3.788 \\
(0.214)\end{array}$ & $\begin{array}{l}3.805 \\
(0.234)\end{array}$ & $\begin{array}{l}3.885 \\
(0.296)\end{array}$ \\
\hline Other controls & \multicolumn{5}{|c|}{$\begin{array}{l}\text { Family background characteristics, head teacher post-graduate education } \\
\text { year dummy, urbanicity dummies. }\end{array}$} \\
\hline Observations & 82,766 & 82,757 & 82,751 & 82,756 & 82,670 \\
\hline R-squared & 0.29 & 0.24 & 0.24 & 0.22 & 0.13 \\
\hline
\end{tabular}

Note: OLS, robust standard errors by means of clustering on school.

* denotes significance on 5 percent level. ** denotes significance on 1 percent level 
Figure 1

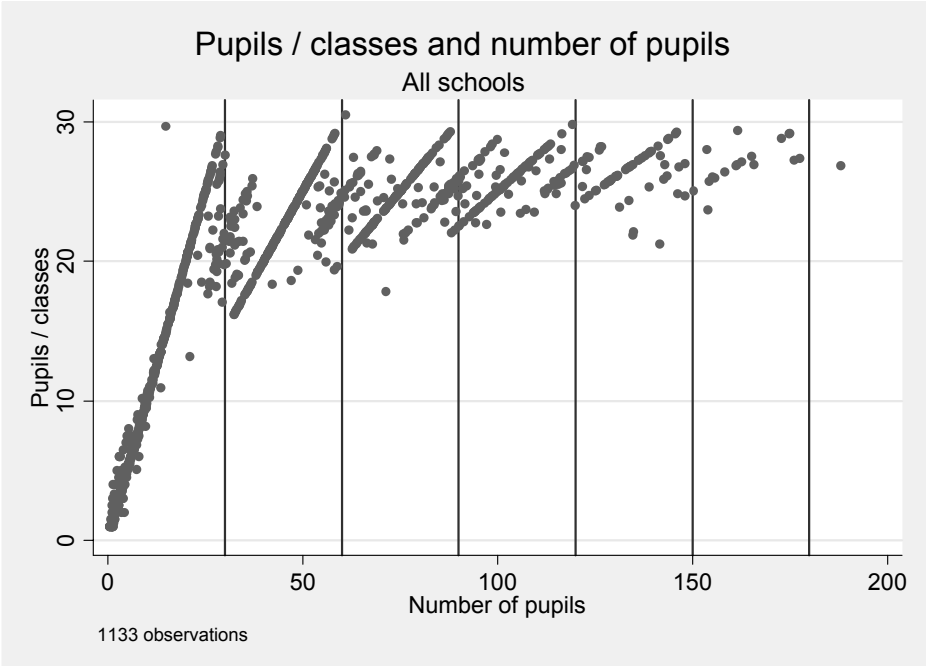

Figure 2

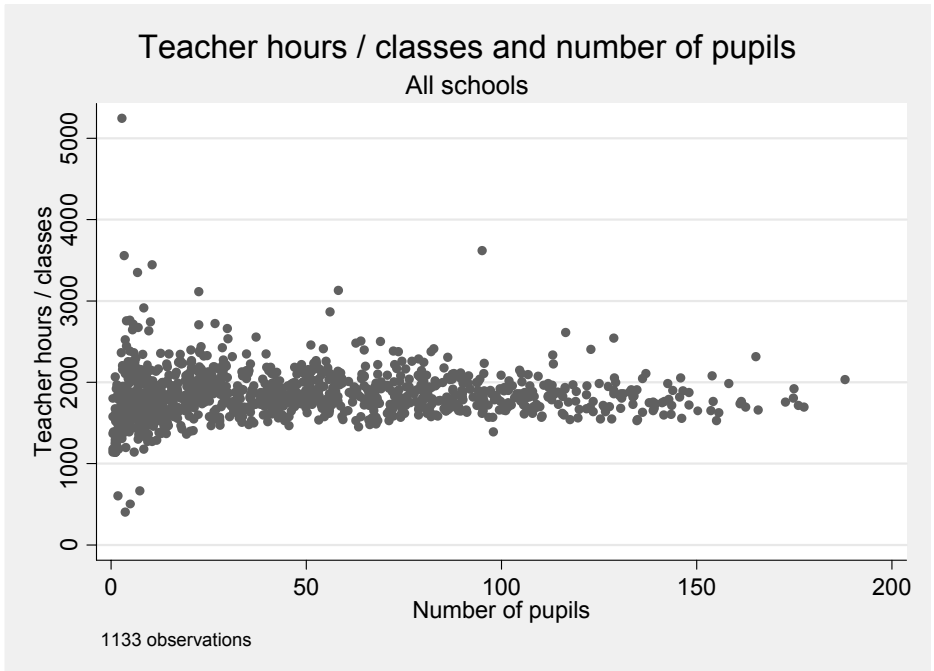

